\title{
Outbreak of vampire bat biting in a Venezuelan village
}

\section{Ocorrência de mordeduras de morcegos vampiros em um povoado da Venezuela}

\author{
Alejandro J. Caraballo $\mathbf{H}$. \\ Centro de Investigaciones de Campo "Dr. Francesco Vitanza" da la Escuela de Malariología y \\ Saneamiento Ambiental "Dr. Arnoldo Gabaldon"
}

\begin{abstract}
An outbreak of 154 cases of vampire bat biting in a four-month period in the gold mine of Payapal, a Venezuelan village, is reported. All patients were bitten during the night and the most bites were on their toes. No complication attributed to the bite was reported. Diagnoses of rabies virus made by means of immunofluorescence were negative. A possible reason for this outbreak may been the development of mining areas, with the inhabitants providing an alternative food source for the bats.
\end{abstract}

Chiroptera. Bites and stings, epidemiology.

\section{Resumo}

Relata-se a ocorrência de 154 casos de mordeduras de morcegos vampiros, no período de quatro meses, em uma mina de ouro na zona de Payapal, povoado da Venezuela. Todos os pacientes foram mordidos durante a noite e com maior freqüência nos pés. Nenhuma complicação foi atribuída às mordeduras. $O$ diagnóstico do vírus rábico, realizado por técnicas de imunofluorescência, foi negativo. Uma possível explicação para esta ocorrência pode estar nas atividades desenvolvidas nas áreas de mineração onde a população se apresenta como alternativa de alimentação para os morcegos.

Chiroptera. Mordeduras e picadas, epidemiologia.

One hundred and forty-five cases of vampire bat biting were reported in a four-month period by local health authorities in the gold-mining village of Payapal, Dalla Costa Municipio, Bolivar State, Southeastern Venezuela. Payapal is situated in a forest area with a mean temperature of $24.6-26{ }^{\circ} \mathrm{C}$ and median relative humidity of $87-89 \%$. The area is en- demic for malaria. There were 659 inhabitants (472 adults and 187 children) forming a stable population and an estimated floating population of 1,000 goldminers. Cattle and horses were reported to have been bitten by bats on two neighboring farms as from just two months before bats began biting humans in Payapal. Vampire bats (Desmodus rotundus) captured 
were confirmed to be carrying rabies virus and extermination measures were taken. Numerous sporadic cases of bat bites in man had occurred in the Dalla Costa village during the last three years.

A team of the Venezuelan Malaria Program and physicians of the Tumeremo Hospital visited the village from July 10 to October 30, 1992 to investigate the outbreak. The patients' ages ranged from one to 69 years (mean: 26 years). All patients were bitten during the night while they were sleeping and bites were recognized on the following morning when small bite marks and/or blood stains were seen on the bed linen. An estimated $70 \%$ of the population dwelling in 295 houses use bednets but biting was also recorded amongst those using bednets. A total of 145 persons were bitten, $86(59 \%)$ of them two to four times. The commonest sites were toes ( $80 \%$ of cases), fingers $(8.2 \%)$, feet $(4.9 \%)$, head $(4.1 \%)$, and nose $(2.7 \%)$. There were no reports of complications such as abscesses at the bite sites. All cases were treated with tetanus toxoid and antirabies vaccine in accordance with the recomendation of the Venezuelan Health Ministry. In the village there were numerous caves resulting from gold exploitation as well as cabins. Bats were netted at separate locations in the village to sample different subpopulations. Locations were selected at which a horse and a donkey

\section{REFERENCES}

1. BATISTA, M. et al. An outbreak of vampire bat bite in a Brazilian village. Trop. Med. Parasitol., 44: 219-20, 1993.

2. LARGHI, O.P. Anticuerpos fluorescentes para rabia. Buenos Aires, Centro Panamericano de Zoonoses, 1975. (Nota Técnica, 8, Rev. 2). were tethered during the night; 250 vampire bats were captured in mist-nets. Two hundred bats were smeared with a paste of $2 \%$ warfarin in vaseline on the mid-dorsum and then released. Frugivorous and insectivorous species of bats were also captured, sometimes in the same roosting sites as $D$. rotundus. Diagnoses for rabies virus, made in the 50 resting bats by means of direct immunofluorescence ${ }^{2}$ with nervous tissue, were negative. Follow-up during the two following years revealed no further cases of bat bites after this episode, nor were there any reports of bovine rabies.

Payapal has no longer existed since 1993 and biting has been reported in nearby villages, but with less intensity. A natural migratory pathway used by vampire bats, exists and results in biannual outbreaks of man-biting in this village. This natural pathway covers an extensive area which is now being delimited. A few cases have been reported along this route in previous decades by the Ministry of Health. This outbreak seems to have been the largest so far reported on the American Continent ${ }^{1,3,4}$ in recent years.

A possible reason for this outbreak may been the development of mining areas, with forest cleaning and rudimentary housing, with the inhabitants providing an alternative food source for bats.

3. LOPEZ, A. et al. Outbreak of human rabies in the Peruvian jungle. Lancet, 339: 408-11, 1992.

4. McCARTHY, T.J. Human depredation by vampire bats (Desmodus rotundus) following a hog cholera campaign. Am. J. Trop. Med. Hyg., 40: 320-22, 1989. 